\title{
Consumer Satisfaction and Profitability: A Dynamic Panel Data Analysis
}

\author{
Alan K.M. $\mathrm{Au}^{1} \&$ Matthew C.H. Yeung ${ }^{1}$ \\ ${ }^{1}$ Lee Shau Kee School of Business and Administration, Open University of Hong Kong, Hong Kong, China \\ Correspondence: Matthew Yeung, Lee Shau Kee School of Business and Administration, Open University of Hong \\ Kong, Homantin, Kowloon, Hong Kong, China Tel: 852-2768 6951. E-mail: myeung@ouhk.edu.hk
}

Received: September 4, 2013

Accepted: September 27, 2013

Online Published: October 7, 2013

doi:10.5430/jbar.v2n2p54

URL: http://dx.doi.org/10.5430/jbar.v2n2p54

\begin{abstract}
This paper uses panel data estimations to examine the link between customer satisfaction and profitability. In so doing it controls for the existence of firm-specific effects which may impact on overall performance and thus gives a more rigorous estimate of the relationship between these two variables. The use of a dynamic estimation also provides important insights into issues relating to causality.
\end{abstract}

Keywords: Customer satisfaction, Profitability, Panel data

\section{Introduction}

The existence of a link between customer satisfaction and business performance is a central premise of modern marketing. Theoretical frameworks to explain this link are well established and there is a growing body of evidence which provides qualified support for the relationship. Most empirical studies rely on cross sectional data and thus have limited ability to control for firm-specific effects. This paper reports the results of a new analysis of the satisfaction-profitability relationship using panel data which, it is argued, provides a more rigorous test of the relationship between the two variables. In addition, by using dynamic panel techniques it is possible to provide further insight into issues relating to causality. The paper begins with a discussion of the modeling issues associated with the satisfaction-profitability relationship. This is followed with a brief discussion of estimation, after which the results and conclusions are presented.

\section{Backgrounds}

Research to date has provided only qualified support for the existence of a link between customer satisfaction and profitability (see for example Anderson and Fornell 1994; Oliver, 1997, Ittner and Larcker, 1998; Yeung and Ennew, 2000). Whether this genuinely reflects ambiguity concerning this relationship or whether it is due to measurement difficulties is more open to debate. Thus far, the majority of empirical studies have relied on cross sectional analysis. Time-series evidence does exist: Fornell et al.'s (2010), Ramasamy and Yeung's (2010) and Yeung et al. (2013) tested the effects of the customer satisfaction index on consumer spending in US and several European countries. Nevertheless, where data is collected regularly (as with customer satisfaction barometers/indices), the relevant information is, in principle, available over time - ie as a panel. Using panel data estimation can provide additional insights into the satisfaction-profitability relationship and greater rigour in testing the relationship. Such an important feature has not been demonstrated by previous studies.

Statistically, panel data estimations have a number of advantages. Panel data models do everything that is possible with a time series model while also controlling for individual-specific, time-invariant variables and addressing unobserved heterogeneity among firms. Panel data has more variability and less collinearity than is typical of cross-section or time-series data which results in more reliable estimates. By pooling information from multiple observations on the same unit, estimation efficiency can be increased (Greene, 1993). The use of panel data in estimating common relationships across firms is particularly appropriate for the current research agenda because it allows the identification of firm-specific effects that control for missing or unobserved variables (Judson and Owen, 1997). In other words, such estimations provide an opportunity to reduce the effects of omitted variables and control for observation-specific effects, thus mitigating some of the problems associated with unobserved heterogeneity which may have affected earlier research.

This latter, statistical, advantage of panel data estimation has important theoretical implications. Customer satisfaction is often identified as a primary 'strategic variable' which firms must address in order to enhance 
performance (e.g. Weber, 2002; Hoque, 2002; Annacker and Hildebrandt, 2002). However, it is recognized that performance may also be influenced by a variety of other factors including industry competitive environment and firm specific factors such as management skill, firm size, resources, assets and competencies and even luck (Caves and Ghemawat, 1986, Teece, 1982; Wernerfelt, 1984). For example, Rumelt (1991), using the PIMS data, found that $8 \%$ of dispersion in firms performance can be explained by industry-factors but $40 \%$ of dispersion in firm performance can only be explained by firm-specific effects.

Thus, profitability may be driven by both firm specific effects and strategic variables such as satisfaction. As these strategic variables often correlate with firm-specific variables, their effects can be difficult to disentangle. A failure to control for unobserved (firm-specific) factors may result in biased estimates of the impact of strategic variables (Jacobson, 1990). Ideally, any analysis of business performance should specifically address these unobservable factors (Annacker and Hildebrandt, 2002). Without the appropriate modeling tools, it is difficult to distinguish the effects of customer satisfaction from other strategic variables. Where this information is not available, but data is collected over space and time, the ability of panel data estimation to control for firm-specific effects, makes it particularly suited for the analysis of the satisfaction-profitability relationship (Ailawadi et al, 1999). With the presence of the aforementioned theoretical and methodological issues, there are strong needs to test the following hypothesis: H1: customer satisfaction is positively related to internal profitability measures, even firms' heterogeneities are controlled for; $\mathrm{H} 2$ : customer satisfaction provides value-valevance information in determining market value or stock prices, even firms' heterogeneities are controlled for. The selected modeling techniques also allow us to address causality issue in the Granger sense. That is, H3: customer satisfaction granger causes firms' profitability.

\section{Method}

Data for the analysis were collected from two sources - the American Customer Satisfaction Index (ACSI available on-line) and Thomson Banker One. Given the limitations associated with the use of organisations' own data (Ittner and Larcker, 1996), and the cost of collecting primary data for a large scale, longitudinal study, the ACSI was identified as the most appropriate source of satisfaction data. Thomson Banker One was chosen because it provided an extensive range of information on both internal performance measures (profitability ratio: gross profit ratio, net profit ratio, return on assets) and external performance measures (stock return and market value). The data period of interest was from 1995-2005 because ACSI data across firms for this period were constructed based on the same conceptual model, whereas variable components were introduced to cater for individual sectoral characteristics after this period. ACSI is constructed based on a thorough analysis of theory and implementation of best practice methodlogy of data collection, measurement and analysis. It uses survey data, collected by telephone interviews, to create latent variable, e.g., customer expectations, perceived product quality, perceived service quality and perceived value to computer the customer satisfaction measurement. It was modified from the first uniform national measurement instructment for customer satisfaction and customer loyalty in Sweden-the Swedish Customer Satisfaction Barometer. The selection of internal and external measures was based on Yeung and Ennew (2001), Yeung and Ennew (2001), Yeung et al. (2001) and Yeung and Ramasamy (2008).

Each of the three internal performance measures of firm is regressed on customer satisfaction to examine the contemporaneous effect of customer satisfaction on profitability (Model 1 to 3of Table 1). Next, the price and return models (Model 4 and 5 of Table 2) are fitted to examine the value-relevance of customer satisfaction. The original idea of fitting the price and return model was to examine the value-relevance of accounting information to the stock market (see Amir et al., 1993; Chen et al., 2001; Eason and Harris, 1991). The return model provides information about whether an accounting amount is promptly reflected in changes in value over the return period, while the price model indicates whether an accounting amount is value relevant with respect to its association with firm value (Barth et al., 2001; Chen and Wang, 2004) Entering customer satisfaction as an independent variable into the two models allows us to examine if customer satisfaction provide new or incremental information to the stock market. The price and return models used by Ohlson (1995) and Chen et al (2001) are employed here.

In estimating these panel data models, two basic estimation methods are available, namely the fixed effects (FE) and the random effects (RE) models. In a FE model, the regressors may be correlated with observation-specific and time effects. In a RE model, the observation-specific effects are assumed to be random and uncorrelated with the regressors. Two popular test statistics are used to validate the assumptions and guide the selection of estimation methods. Breusch and Pagan's Lagrange multiplier test (LM) statistic is used to assess whether the data may be treated as pooled (estimate with OLS) or whether panel data estimation is required. Hausman's specification test is used to guide the choice between FE and RE when panel estimation is to be used. Note that two ways effects models 
are estimated in which the time effects are taken into accounted.

Additionally, in order to further examine the lagged effect of customer satisfaction on profitability and to test the present of causality in the customer satisfaction-profitability relationships. A second set of models (Model 6 to 8 of Table 3) that are estimated in the form of dynamic panel data models are considered. In these models, profitability measure of firm $i$ at time $t$ is regressed on its own lagged value (e.g. profit at $t-1$ ) as well as lagged customer satisfaction. This specification provides a typical test for causality, defined by Granger $(1969, \mathrm{p} 428)$ as "Xt is causing Yt if we are better able to predict Yt using all available information than if the information apart from Xt had been used". Since the notion of 'all available information' is not easy to define, Granger's suggestion that Yt should be regressed on its own lags and a set of lagged Xt(s) has became the norm. If the coefficient(s) on the lagged Xt(s) are statistically significant, then one could conclude that $\mathrm{Xt}$ is granger cause Yt. Introducing a lagged dependent variable as a regressor creates a number of problems due to the fact that the lagged dependent variable and the error term are correlated, which renders standard estimators (e.g. FE and RE) of panel data biased. As an alternative, this study adopts the 2-step GMM-type estimation approach of dynamic panel data modeling suggested by Arellano and Bond (1991). Again, the price and return models are refitted in the manner of dynamic panel data (Model 9 and 10 of Table 4).

\section{Results}

The analysis proceeded by first estimating the LM test statistics to assess the suitability of OLS. For model 1 to 3 reported in Table 1, all the LM statistics were significant at the 1\% level, which implies that panel data estimations are preferable over OLS. The Hausman test was used to guide the choice between FE and RE estimations. In this case, the null hypothesis (RE is preferred over FE) is not rejected at the 5\% significance level, suggesting that the random effects procedure is more appropriate for the estimations. Collectively, the coefficients of CS in the three fitted models are statistically significant $(\mathrm{p}<0.05)$, confirming the present of contemporaneous relationship between customer satisfaction and profitability. Note that the reported R2s for RE estimations are necessarily smaller than for other estimator (Verbeek, 2004) and should not be interpreted as the usual R2 estimated by OLS. Especially, R2s have little statistical meaning in the case of dynamic panel data model. One should be focused on the significance of the coefficients.

Table 1 . Profitability Ratio ${ }_{i t}=f\left(\right.$ Customer Satisfaction $\left._{i t}\right)$

\begin{tabular}{lllll}
\hline Dependent Variable & Specifications & Intercept & CS & Goodness-of-Fit \\
\hline Model 1: & Random Effects & $-26.448^{* * *}$ & $0.460^{* * *}$ & $\mathrm{R}^{2}=0.049$ \\
Gross profit ratio & Hausman $=0.06$ & 6.917 & 0.091 & $s^{2}=196339$ \\
$(\mathrm{~N}=1218)$ & $\mathrm{LM}=640.08^{* * *}$ & $(0.000)$ & $(0.000)$ & \\
& & & & \\
Model 2: & Random Effects & $-31.240^{* * *}$ & $0.480^{* * *}$ & $\mathrm{R}^{2}=0.037$ \\
Net profit ratio & Hausman $=0.77$ & 7.026 & 0.093 & $s^{2}=232097$ \\
$(\mathrm{~N}=1217)$ & $\mathrm{LM}=156.45^{* * *}$ & $(0.000)$ & $(0.000)$ & \\
& & & & \\
Model 3: & Random Effects & $-17.891 * * *$ & $0.321 * * *$ & $\mathrm{R}^{2}=0.080$ \\
Return on assets & Hausman $=2.27$ & 4.176 & 0.055 & $s^{2}=84246.1$ \\
$(\mathrm{~N}=1193)$ & $\mathrm{LM}=156.22 * * *$ & $(0.000)$ & $(0.000)$ & \\
\hline
\end{tabular}

*Significant at $10 \%$ level. $* *$ Significant at $5 \%$ level. ${ }^{* * *}$ Significant at $1 \%$ level. N: number of observations included.

Turning to the price (model 4) and return (model 5) models which are reported in Table 2, the corresponding LM statistics and Hausman test statistics guided us to estimate the two models by the fixed effects procedure. The coefficients of CS are significant and insignificant in the price and return model, respectively. This is a sign that customer satisfaction is value relevant with respect to its association with firm value and confirmed that customer satisfaction measures could provide some incremental information to the stock market. 
Table 2. Price and Return Models

\begin{tabular}{|c|c|c|c|c|c|c|}
\hline $\begin{array}{l}\text { Dependent } \\
\text { Variable }\end{array}$ & Specifications & Intercept & $\mathrm{CS}_{\text {it }}$ & $\mathbf{N I}_{\text {it }}$ & $\mathrm{BV}_{\mathrm{it}}$ & $\begin{array}{l}\text { Goodness } \\
\text {-of-Fit }\end{array}$ \\
\hline $\mathrm{MV}_{\text {it }}$ & Fixed Effects & -10.717 & $0.483^{* * *}$ & $0.885^{* * *}$ & $0.335 * * *$ & $\mathrm{R}^{2}=0.669$ \\
\hline$(\mathrm{N}=1087)$ & $\mathrm{H}=49.29 * * *$ & 9.999 & 0.133 & 0.140 & 0.034 & $s^{2}=93602.232$ \\
\hline & $\mathrm{LM}=1030.53 * * *$ & $(0.284)$ & $(0.000)$ & $(0.000)$ & $(0.000)$ & \\
\hline
\end{tabular}

\begin{tabular}{|c|c|c|c|c|c|c|}
\hline \multicolumn{7}{|c|}{ Model 5: Return Model: $\operatorname{RET}_{\mathrm{it}}=\alpha_{\mathrm{i}}+\beta_{1}\left[\mathrm{CS}_{\mathrm{it}}\right]+\beta_{2}\left[\mathrm{E}_{\mathrm{it}} / \mathrm{P}_{\mathrm{it}-1}\right]+\beta_{3}\left[\Delta \mathrm{E}_{\mathrm{it}} / \mathrm{P}_{\mathrm{it}-1}\right]+\varepsilon_{\mathrm{it}}$} \\
\hline Dependent & Specifications & Intercept & $\mathbf{C S}_{\text {it }}$ & $\mathbf{E}_{\mathrm{it}} / \mathbf{P}_{\mathrm{it}-1}$ & $\Delta \mathbf{E}_{\mathrm{it}} / \mathbf{P}_{\mathrm{it}-1}$ & Goodness \\
\hline Variable & & & & & & -of-Fit \\
\hline $\mathrm{RET}_{\mathrm{it}}$ & Fixed Effects & -48.125 & 0.816 & $23.773 * * *$ & -2.271 & $\mathrm{R}^{2}=0.207$ \\
\hline \multirow[t]{2}{*}{$(\mathrm{N}=1069)$} & $\mathrm{H}=13.70 * * *$ & 41.948 & 0.555 & 4.769 & 3.987 & $s^{2}=1564411.982$ \\
\hline & $\mathrm{LM}=378.96^{* * *}$ & 0.251 & 0.141 & 0.000 & 0.569 & \\
\hline
\end{tabular}

$\mathrm{MV}_{\mathrm{it}}$ : market value of equity per share of firm $i$ at $t ; \mathrm{CS}_{\mathrm{it}}$ : customer satisfaction of firm $i$ at $t$; $\mathrm{NI}_{\mathrm{it}}$ : net income per share of firm $i$ at $t$; $\mathrm{BV}_{\mathrm{it}}$ : book value of equity per share of firm $i$ at $t$; $\mathrm{H}$ : Hausman test; $\mathrm{RET}_{\mathrm{it}}$ : cumulative stock return of firm $i$ at $t ; \mathrm{CS}_{\mathrm{it}}$ : customer satisfaction of firm $i$ at $t ; \mathrm{E}_{\mathrm{it}} / \mathrm{P}_{\mathrm{it}-1}$ : earning per share over beginning price of firm $i$ at $t ; \Delta \mathrm{E}_{\mathrm{it}} / \mathrm{P}_{\mathrm{it}-1}$ : change in earning per share over beginning price of firm $i$ at $t^{*}$; Significant at $10 \%$ level. **Significant at $5 \%$ level. $* * *$ Significant at $1 \%$ level.

Table 3. Profitability Ratio ${ }_{i t}=f\left(\right.$ Profitability Ratio $_{\mathrm{it}-1}$, Customer Satisfaction $\left._{\mathrm{it}-1}\right)$

\begin{tabular}{|c|c|c|c|c|c|}
\hline $\begin{array}{l}\text { Dependent Variable } \\
\text { (DV) }\end{array}$ & Specifications & Intercept & Lagged DV & $\Delta \mathrm{CS}_{\mathrm{it}-1}$ & $\begin{array}{l}\text { Goodness } \\
\text {-of-Fit }\end{array}$ \\
\hline Model 6: & Sargan $=73.18$ & 0.107 & $-0.047 * * *$ & $0.271 * * *$ & $\mathrm{R}^{2}=0.107$ \\
\hline $\begin{array}{l}\Delta \text { Gross profit ratio }_{\text {it }} \\
(\mathrm{N}=967)\end{array}$ & $\begin{array}{l}\operatorname{AR}(1)=-2.47^{* *} \\
\operatorname{AR}(2)=0.87\end{array}$ & $\begin{array}{l}0.345 \\
(0.002)\end{array}$ & $\begin{array}{l}0.005 \\
(0.000)\end{array}$ & $\begin{array}{l}0.020 \\
(0.000)\end{array}$ & $s^{2}=13.182$ \\
\hline $\begin{array}{l}\text { Model 7: } \\
\Delta \text { Net profit ratio } \\
(\mathrm{N}=966)\end{array}$ & $\begin{array}{l}\text { Sargan }=73.66 \\
\operatorname{AR}(1)=-1.86^{*} \\
\operatorname{AR}(2)=0.03\end{array}$ & $\begin{array}{l}0.168 * * * \\
0.389 \\
(0.000)\end{array}$ & $\begin{array}{l}-0.083^{* * * *} \\
0.001 \\
(0.000)\end{array}$ & $\begin{array}{l}0.242 * * * \\
0.194 \\
(0.000)\end{array}$ & $\begin{array}{l}\mathrm{R}^{2}=0.216 \\
s^{2}=18.119\end{array}$ \\
\hline $\begin{array}{l}\text { Model 8: } \\
\Delta \text { Return on assets } \\
(\mathrm{N}=946)\end{array}$ & $\begin{array}{l}\text { Sargan }=87.53^{* *} \\
\operatorname{AR}(1)=-1.79^{*} \\
\operatorname{AR}(2)=1.44\end{array}$ & $\begin{array}{l}-0.147 \\
0.020 \\
(0.000)\end{array}$ & $\begin{array}{l}0.152 \\
0.001 \\
(0.000)\end{array}$ & $\begin{array}{l}0.299 \\
0.010 \\
(0.000)\end{array}$ & $\begin{array}{l}\mathrm{R}^{2}=0.063 \\
s^{2}=8.893\end{array}$ \\
\hline
\end{tabular}

*Significant at $10 \%$ level. **Significant at $5 \%$ level. $* * *$ Significant at $1 \%$ level.

In the further analysis, dynamic panel data models are fitted. The dependent variables were regressed on its own lag as well as the lagged independent variables. The fitted models of lagged effects of customer satisfaction on profitability ratio are reported in Table 3. The fitted model of lagged effects of customer satisfaction on price and return are reported in Table 4. Note that Arellano and Bond (1991)'s estimation approach requires data transformations to eliminate the firm effects leading us to estimate the differenced equation. Estimating such differenced models also avoided the problem of spurious or nonsense regression. To diagnose the specifications of the model, Sargan (1964) test of overidentifying restrictions to test the validity of the instruments is employed. To test the consistency of estimators, we test if the differenced residuals are evidence of significant negative first-order 
serial correlation and insignificant negative first-order serial correlation. In other words, roughly speaking, a dynamic panel data model is said to be correctly specified if it satisfy the following three conditions: it does not reject the null hypothesis of the validity of instruments; it rejects the null hypothesis of no first-order serial correlation in the differenced residuals; it does not reject the null hypothesis of no second-order serial correlation in the differenced residuals (see Doornik and Hendry, 2001, pp. 69).

Table 4. Profitability Ratio ${ }_{\text {it }}=f\left(\right.$ Profitability Ratio $_{\text {it-1 }}$, Customer Satisfaction $\left._{\text {it-1 }}\right)$

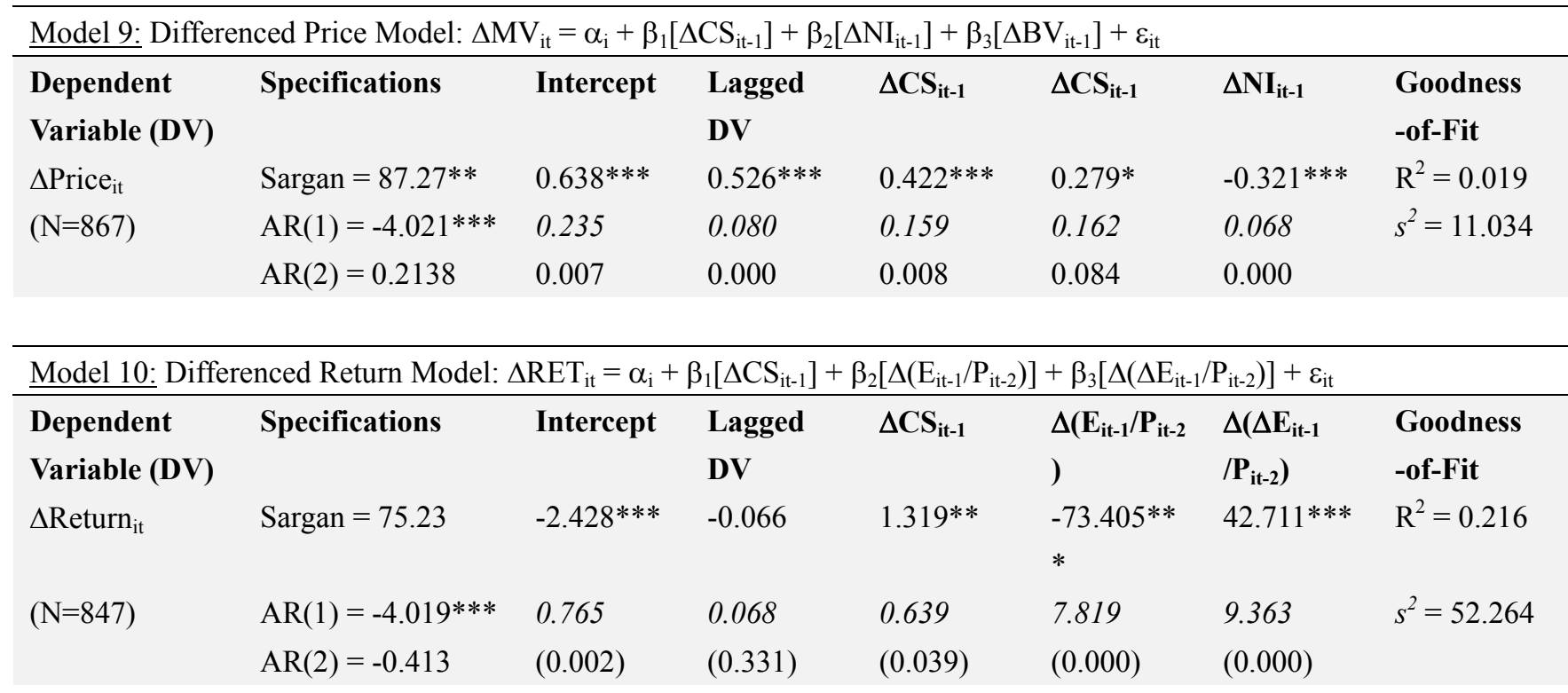

$\Delta$ : first difference operator; *Significant at $10 \%$ level. **Significant at $5 \%$ level. ${ }^{* *}$ Significant at $1 \%$ level.

Only model 6,7 and 10 satisfied the conditions described above at the $10 \%$ significance, leading us to drop model 8 and 9 from interpretation. In the fitted model 6 and 7 displayed in Table 3, the coefficients of the differenced customer satisfaction are positive and very significant. In other words, there is a sign of existence of causality from customer satisfaction to profitability. In the fitted model 10 displayed in Table 4, that is the return model, the coefficients of the differenced customer satisfaction are positive and very significant. Again, this is a sign of existence of causality from customer satisfaction to return. Collectively, the lagged effects of customer satisfaction on both internal and external profitability are positive and statistical significant.

\section{Discussion}

This paper has used panel data estimation to provide further evidence on the relationship between customer satisfaction and profitability. For both the internal and external financial performance, the evidence presented in the study suggests that customer satisfaction generally has a significant, positive contemporaneous impact on most but not all performance indicators. The use of dynamic panel techniques to address causality between customer satisfaction and profitability. The results suggest that there is some evidence of causality in relation to internal measures of performance as well as external measures of performance.

Since we modelled the customer satisfaction-profitability relationships using both the level and differenced data, it is confirmed that the relationships exist in both long-run and short-run. Importantly, we showed not only the contemporaneous relations but the lagged relations. Our results of this robust analysis provide further support for the premise underlying modern marketing - namely that customer satisfaction does affect profitability, regardless of the choice of profitability performance measures or/and choice of transformation of data (e.g. level of differenced data). The results are roughly in line with Yeung and Ennew (2001), Yeung and Ennew (2001) and Yeung et al. (2001)'s studies in which they did not address causality issues and lagged effects. Furthermore, customer satisfaction does provide incremental information to the stock market. The current study provides technical concepts and analysis implications to a wide audience to a wide range of audiences. For practitioners, this work highlights the importance of customer satisfaction as a strategic variable. For investors, the present study suggests that customer-related 
information should regard as value relevant information for stock selection since they reflect the fundamental performance and potential of firms. For accountants, the present research has firmly proved that customer satisfaction is an important performance activity that does directly contribute to various financial goals of organizations, it is worth selecting customer satisfaction into the selection of measurements for balanced scorecard systems. For an academic audience, the paper highlights the potential value of panel data techniques in obtaining more rigorous estimated of marketing relationships. Three limiations must be addressed. First, the research focuses on a single country where purchasing power and disposable income are high and the influence of globalization is prevalent, while the values, attitudes and behaviors of other countries' consumers might be very different. Thus, the generalizability of the research could be limited. Second, the research is also based on slightly inconsistent sample across models, which might not be as adequate as if we had a large sample to construct a balanced panel. Finally, the analysis was based entirely on the use of secondary data. The qualitative information from consumers that can be obtained from the analysis of primary data was not considered. Thus, the details at the micro-level have not been clarified by the present study. The present study has discussed and showed the needs for controlling firms' heterogeneities when linking marketing efforts to firm performance; future direction into those marketing efforts (for instance, efforts in improving brand value or advertising elasticity) that related to firm performance could be undertaken with the same research settings presented by the current study.

\section{References}

Ailawadi, K.L., Farris, P.W. \& Parry, M.E. (1999). Market share and ROI: observing the effect of unobserved variables, International Journal of Research in Marketing, 16(1), pp. 17-33. http://dx.doi.org/10.1016/S0167-8116(98)00012-3

Amir, E., Harris, T. \& Venuti, E. (1993). A comparison of the value-relevance of US versus non-US GAAP accounting measures using 20-F reconciliations, Journal of Accounting Research, 31, pp. 230-264. http://dx.doi.org/10.2307/2491172

Annacker, D. \& Hildebrandt, L. (2002). Unobservable effects in structural models of business performance, Journal of Business Research, Vol. 57(5), 507-517. http://dx.doi.org/10.1016/S0148-2963(02)00317-X

Anderson, E.W. \& Fornell, C. (1994). A customer satisfaction research prospectus, In Rust, R.T. and Oliver, R.L. (eds), Service Quality: New Directions in Theory and Practice, Sage: Thousand Oaks (CA), pp. 241-268. http://dx.doi.org/10.2307/2297968

Arrelano, M. \& Bond, S. (1991). Some test of specification for panel data: Monte Carlo evidence and an application to employment equations, Review of Economic Studies, 58(2), pp. 277-297.

Barth, M.E., Beaver, W.H. \& Landsman, W.R. (2001). The relevance of the value relevance literature for financial accounting standard setting: Another view, Journal of Accounting and Economics, 30, pp. 77-103. http://dx.doi.org/10.1016/S0165-4101(01)00019-2

Breusch, T.S.; Pagan, A.R. (1979). "Simple test for heteroscedasticity and random coefficient variation". Econometrica, Vol. 47 (5), pp. 1287-1294. http://dx.doi.org/10.2307/1911963

Caves, R.E. \& Ghemawat, P. (1986). Capital commitment and profitability; an empirical investigation, Oxford Economic Papers, Vol. 38(0), pp 94-110.

Chen, C.J.P., Chen, S. \& Su, X. (2001). Is accounting information value-relevant in the emerging Chinese stock market?, Journal of International Accounting, Auditing and Taxation, 10(1), pp. 1-22. http://dx.doi.org/10.1016/S1061-9518(01)00033-7

Chen, S. \& Wang, Y. (2004). Evidence from China on the value relevance of operating income vs. below-the-line items, The International Journal of Accounting, 39(4), pp. 339-364. $\mathrm{http}: / / \mathrm{dx}$.doi.org/10.1016/j.intacc.2004.06.012

Doornik, J. A. \& Hendry, D.F. (2001). Econometric Modelling using PcGive, Volume 3, Timberlake Consultants Ltd.

Granger, C.W.J. (1969), Investigating causal relations by econometric models and cross-spectral methods, Econometrica, 37(3), pp. 424-459. http://dx.doi.org/10.2307/1912791

Greene, W.H. (1993). Econometric Analysis, Macmillian Publishing Com: New York.

Eason, P.D. \& Harris, T.S. (1991). Earnings as an explanatory variable for returns, Journal of Accounting Research, 29, pp. 19-36. http://dx.doi.org/10.2307/2491026

Hoque, Z., (2002). Using journal articles to teach public sector accounting in higher education, Journal of 
Accounting Education, 20(3), pp. 139-161. http://dx.doi.org/10.1016/S0748-5751(02)00006-4

Ittner, C.D. \& Larcker, D.F. (1996). Measuring the impact of quality initiatives on firm financial performance, Advances in the Management of Organisational Quality, 1 JAI Press, London, pp. 1-37.

Ittner, C.D. \& Larcker, D.F. (1998). Are Non-financial Measures Leading Indicators of Financial Performance? An Analysis of Customer Satisfaction, Working Paper, University of Pennsylvania.

Jacobson, R. (1990). Unobservable effects and business performance, Marketing Science, 9(1), pp. 74-85. http://dx.doi.org/10.1287/mksc.9.1.74

Ohlson, J. (1995). Earnings, book values, and dividends in equity valuation, Contemporary Accounting Research (Spring) pp. 661-687. http://dx.doi.org/10.1111/j.1911-3846.1995.tb00461.x

Oliver, R.L. (1997). Satisfaction: A Behavioral Perspective on the Consumer, Mcgraw Hill International: New York.

Rumelt, R.P. (1991). How much does industry matter? Strategic Management Journal, 12(3), pp. 167-185. http://dx.doi.org/10.1002/smj.4250120302

Teece, D.J. (1982). Towards and Economic Theory of the Multiproduct Firm, Journal of Economic Behaviour and Organisation, 3(1), pp. 39-63. http://dx.doi.org/10.1016/0167-2681(82)90003-8

Verbeek, M. (2004). A Guide to Modern Econometrics $2^{\text {nd }}$ Edition, Wiley.

Weber, J.A. (2002). Managing the marketing budget in a cost-constrained environment, Industrial Marketing Management, 31(8) pp. 705-717. http://dx.doi.org/10.1016/S0019-8501(01)00191-2

Wernerfelt, B. (1984). A resource-based view of the firm, Strategic Management Journal, 5(2), pp. 171-180. http://dx.doi.org/10.1002/smj.4250050207

Yeung, M. \& Ennew, C. (2000). From customer satisfaction to profitability, Journal of Strategic Marketing, Vol. 8 (4), pp. 313-326. http://dx.doi.org/10.1080/09652540010003663

Yeung, M. \& Ennew, C. (2001). Measuring the Impact of Customer Satisfaction on Profitability: A Sectoral Analysis, Journal of Targeting, Measurement and Analysis for Marketing, Vol. 10 (2), pp. 106-116. http://dx.doi.org/10.1057/palgrave.jt.5740038

Yeung, M., Lee, C.G. \& Ennew, C. (2001). Customer Satisfaction and Profitability: A Reappraisal of the Nature of the Relationship, Journal of Targeting, Measurement and Analysis for Marketing, Vol. 11 (1), pp. 24-33. http://dx.doi.org/10.1057/palgrave.jt.5740064

Yeung, M. \& Ramasamy, B. (2008). Brand Value and Firm Performance Nexus: Further Empirical Evidence, Journal of Brand Management, Vol. 15, (5), pp. 322-335. http://dx.doi.org/10.1057/palgrave.bm.2550092 